\title{
Components of the Vote for Non-Independence Parties: Regional Elections in Catalonia 2017
}

\author{
Nieves Lagares, Elba Maneiro, Alfonso A. López \\ University of Santiago de Compostela, Santiago de Compostela, Spain \\ Email: mnieves.lagares@usc.es
}

How to cite this paper: Lagares, N., Maneiro, E., \& López, A. A. (2020). Components of the Vote for Non-Independence Parties: Regional Elections in Catalonia 2017. Open Journal of Political Science, 10, 383-406.

https://doi.org/10.4236/ojps.2020.103024

Received: March 5, 2020

Accepted: June 2, 2020

Published: June 5, 2020

Copyright () 2020 by author(s) and Scientific Research Publishing Inc. This work is licensed under the Creative Commons Attribution International License (CC BY 4.0).

http://creativecommons.org/licenses/by/4.0/

\begin{abstract}
The lengthy political crisis in Catalonia highlights the incapacity of the Spanish Government and the Generalitat of Catalonia to find a political solution to this conflict. Facing a situation of this exceptionality and so prolonged in time, an innumerable number of articles and research papers have been published from Political Science. However, very few authors have decided to tackle the influence of emotions on the voting decisions of the Catalans; and even fewer, through a quantitative analysis. In this artcile, we decided to analyse the elements that compose the vote for the main non-independence political parties (PSC and C's) in the 2017 Catalan elections, including components of an emotional nature. To this end, we will use the survey carried out by the Equipo de Investigaciones Politicas to develop two structural equation models (SEM), one for each of these parties, in which we will incorporate emotions along with other "classic" voting variables.
\end{abstract}

\section{Keywords}

Catalan Elections, Emotions, Vote, Non-Independence Parties, Procés

\section{Introduction}

In the last few years, the debate about the situation in Catalonia has been mimicked by the struggle between two antagonistic positions: the independence of Catalonia and the immobility of the Spanish government. In this way, the discussion has become increasingly sterile, with each of these positions becoming entrenched in their polarised arguments while other alternative options are being ignored. Between defending Catalonia's permanence within the current State of Autonomies and defending Catalonia's independence from the Spanish state, we find various political-territorial solutions to the Catalan conflict, ranging from a new federal design for Spain to the concession of a new fiscal status for 
the Catalan territory.

Undoubtedly, it is interesting to reflect on how it is possible that these different alternatives around the political-territorial design have been left in the background of the more mediatic debate; especially taking into account that the different surveys carried out in Catalonia indicate that the Catalan citizenship does not indicate as its ideal option either of these two options (central state or independence) and would prefer to opt for other political-territorial options. We must ask ourselves why, despite the fact that $49.5 \%$ of Catalans are in favour of the procés, only $30 \%$ of them believe that Catalonia should be independent from the Spanish State (Máiz \& Lagares, 2017; Máiz, Lagares, \& Pereira, 2018). Even from a more academic perspective, many studies and publications have ignored the analysis of the components of voting for non-independence parties in Catalonia. However, we can ask ourselves whether the electoral behaviour of the Catalans has been reflecting this divergence between political offer and preference. To explore some of these concerns, we have decided to focus on the results obtained by the main political parties that represent the non-independence option in Catalonia, Ciutadans de Catalunya (C's) and the Partit dels Socialistes de Catalunya (PSC), and which factors have influenced the vote for these political groups in the past regional elections of 2017.

If we were to establish a brief chronology of the Catalan conflict, we would possibly identify the year 2005 as the starting point, when the Catalan Parliament approved a reform of its Estatut that included a new set of sovereign rights. A modified version was approved by the Spanish Parliament, and finally ratified by the Catalan citizenship in 2006 through a referendum with a participation of $49 \%$, and with the support of $74 \%$ of the votes. Shortly afterwards, the main opposition party in the Spanish Parliament, the Partido Popular (PP), filed a lawsuit in the Tribunal Constitucional (TC) against the new Catalan Estatut. Four years later, in 2010, the TC resolved the lawsuit that legalized most of the Estatut, but annulled all new sovereignty claims.

That same year, Convergència i Unió (CiU), which had governed Catalonia from 1980 to 2003, won the Catalan elections and recovered the government of the Generalitat from the Partit dels Socialistes de Catalunya (PSC). CiU, which had governed Catalonia from 1980 to 2003, gradually changed its moderate discourse to one that was explicitly pro-independence, reflecting and encouraging the division of increasingly polarised public opinion. The electoral advance in 2012 and, later, in 2015 of the regional elections, predicted the plebiscitary nature of the electoral processes on the possible independence of Catalonia, perhaps at first, with a more tactical objective of deviating attention from the management of the Catalan government, but which introduced an unknown dimension into Catalan and also Spanish politics. In 2012, the Catalan president Artur Mas brought forward the regional elections by two years and $\mathrm{CiU}$ would once again be the most voted candidate and, with the support of the independentist party Esquerra Republicana de Catalunya (ERC), would be sworn in as presi- 
dent. In 2015, he would again call elections in advance, presenting them to President Mas as elections in which the voters would have to decide on the political and territorial future of Catalonia. A reflection of this is the common candidacy with which the unitary block of pro-independence parties (CIU and ERC) presented itself (JuntspelSí, JxSÍ), in which Artus Mas took a step back and withdrew as a candidate. JxSí, which would become the most voted political group in 2015, and which forced Artur Mas to resign from the presidency of the Generalitat in the face of pressure from the pro-independence political party CUP, in favour of Carles Puigdemont. After more than a year of confrontation between the central government and the Catalan government, on 1 October 2017, the Generalitat of Catalonia called a referendum on self-determination, after which Catalan President Carles Puigdemont proclaimed Catalonia's independence from the Spanish state. This proclamation is made despite the fact that the TC had suspended the Law of self-determination referendum of Catalonia approved by the Catalan Parliament and such suspension annulled the binding nature of the referendum. After the unilateral declaration of independence, the Spanish president Mariano Rajoy would apply the article 155 of the Spanish Constitution (the first and so far the only occasion in the Spanish democracy) and called elections in Catalonia on 21 December 2017. These elections confirmed the construction of a new model of political competition around the so-called Catalan procés, which would undoubtedly be presented as a plebiscite on the future of Catalonia and its relationship with Spain, which probably goes far beyond the designs of its original actors.

The way in which the conflict has been escalating in recent years, with evident features of nationalism based on ethnicity and passion but also with clear economic demands; the crucial role of the media in the framing of the procés as well as the referendum of October 1st and the increasing polarization of the political debate have made the situation in Catalonia the perfect chimera to analyse how emotions affect the political behaviour of citizens, thus introducing an innovative variable in this type of study. Therefore, in this paper we will analyse the components of voting for PSC and C's by adding the impact of emotions to the traditional variables, using the study carried out by the Equipo de Investigaciones Políticas (EIP) after the Catalan elections of 2017, Political Study Emotions in Catalonia. Our main objective is to determine how the vote is configured for these non-independent parties.

This article is structured in six sections. In the first, we will address the theoretical framework and those previous works that have helped us design our research questions as in our survey questionnaire. In the next, we present the objectives and the research questions presented, as well as the analysis methodology we have followed. Next, we present the study of the PSC and C's voters as well as the multivariate analysis of the vote to these political groups in the 2017 regional elections in Catalonia. The last two sections will present the results and final conclusions of this article. 


\section{Theoretical Foundations}

The 2017 regional elections in Catalonia took place in a scenario of exceptionality and political tension that was presented as the ideal context for the study of emotions in politics. Emotions, as an inherent part of information processing and political stimuli, are even more latent in such an environment.

The traditional dominant view in Political Science to analyse voter behaviour was based on rationalist postulates, maintaining an iron dichotomy between reason and emotion. However, in the decade of the 90's, new contributions from different disciplinary areas such as psychology or neuroscience have made us consider the once unquestionable hyper-rationalist postulates and “(...) recuperar la capital articulación emotiva/cognitiva de la política” (Máiz, 2010: p. 42). The incorporation of emotions as cognitive elements in the analysis of political behaviour means that we must rethink emotions as decisive elements in the decision-making process, which in the political arena would affect issues such as mobilisation, contestation, protest or the construction of identities (ibid).

Following the work of Marcus (2000), we identified three stages in the study of the relationship between emotions and politics, highlighting the tension between this supposed rationality and the political behaviour of citizens in contemporary societies. Thus he identifies three stages from the 1970s to the present. The first of these stages focuses on identifying the factors that cause a majority group to turn towards authoritarianism, using a psychoanalytic approach to leaders. The second has its turning point in the availability of the survey as a methodology and focusing on authoritarian leaderships. The third of these stages is characterized by findings in the field of neuroscience that propose to interpret emotions as a product of the neuronal process (Vasilopoulos \& Marcus, 2017). Thus, until approximately two decades ago, political science thought of emotion as the expression of personality traits, or as the result of cognitive processes. However, since 1990 it has been argued that assessments that arise from emotional processes, independent of previous or concurrent cognitive processes, can influence not only emotional expression but also thoughts, decisions and political behaviour (Marcus, 2000).

If anything characterizes the study of emotions, it is the lack of agreement on basic concepts, as well as on the identification of the most relevant emotions. At the EIP we have opted for the model proposed by Marcus since his theoretical work is based on interesting empirical findings. Thus, the Theory of Affective Intelligence (AIT) will guide the theoretical part of our work and the methodological developments of Marcus and his colleagues, our questionnaire design. But, first of all we must present the set of emotions we study and how we do it. In our questionnaire we asked for a total of thirteen emotions that we classified into three emotional dimensions (Table 1):

"So when do we think about politics? When our emotions tell us to do" (Marcus, Neuman, \& MacKuen, 2000: p. 1), thus Marcus, Russell Neuman and MacKuen defend without hesitation the role of emotions in politics. They present in this work the theory of Affective Intelligence (AIT) in which they 
Table 1. Emotional dimensions.

\begin{tabular}{|c|c|c|}
\hline \multicolumn{3}{|c|}{ Emotional Dimensions } \\
\hline & 1) & Quiet \\
\hline Enthusiasm & 2) & Enthusiastic \\
\hline Positive-assertive emotions & 3) & Hopeful \\
\hline & 4) & Proud \\
\hline \multirow{6}{*}{$\begin{array}{c}\text { Anxiety } \\
\text { Emotions linked to uncertainty }\end{array}$} & 5) & Disgusted \\
\hline & 6) & Afraid \\
\hline & 7) & Worried \\
\hline & 8) & Angry \\
\hline & 9) & Anxious \\
\hline & 10) & Hateful \\
\hline Aversion & 11) & Bitter \\
\hline \multirow[t]{2}{*}{ Negative-aggressive emotions } & 12) & Resentful \\
\hline & 13) & Contempt \\
\hline
\end{tabular}

Source: Own figures.

claim that the human mind employs emotional assessments of threat and novelty to attract attention. The basic postulate of AIT is that individuals accumulate a repertoire of habits in order to manage the large number of tasks we face in our daily lives, including those in the field of politics. As part of the evolutionary process, we humans have developed two distinct emotional systems: the dispositional system and the surveillance system. The former monitors our daily interactions with the world, assessing the success and failure of routine behaviours. The second points out the novelty or threat in the environment and indicates the need to re-evaluate our beliefs and routine preferences. These cognitive-emotional mechanisms are also used when we encounter political stimuli. Equally important is the ability to modify these routines when we are faced with a new situation. The AIT affirms that in order to change these routines, certain emotional signals must be present to cause the surveillance system to be activated. Applied to politics, the emotion that would trigger the alarm system would be the anxiety dimension, a combination of restlessness and fear.

Thus, the aversion dimension would be activated in the presence of a threat and the anxiety dimension when the degree of normality is altered. In other words, in contexts characterised by uncertainty, such as in Catalonia. Therefore, generally when voters experience anxiety they pay more attention to current factors and stop using partisan identity or ideological convictions as a guide. Therefore, if we assume a positive correlation with the existence of new information and the decrease in the importance of partisan identification, as well as ideological and nationalist self-placement; we can deduce the importance of developing a persuasive discourse in these contexts of uncertainty (Marcus, Neuman, \& MacKuen, 2017). In the framework of these statements, this research arises to offer a cognitive-emotional explanation of voting behaviour in contexts of uncertainty such as that experienced by Catalonia.

\section{Objectives and Methodology}

In the present study, we analyse the elements that make up the vote for the two 
main non-independence parties in the last regional elections of 2017 in Catalonia and whether or not we can point to significant differences between them.

In addition, this general objective can be broken down into several specific objectives: 1) Which is the specific weight that the emotional component has had in the voting decision; 2) To which extent the procés has been a vertebral element of said decision; 3) Which are the effects that the initiatives carried out by the Spanish Government after the unilateral declaration of independence by the Catalan Parliament have had on the voting behaviour of the non-independence parties; and finally, 4) We may or may not speak of a homogeneous whole as far as the definition of the vote for the non-independence parties is concerned, or they move on the basis of different decision elements.

These objectives have in turn led us to raise a number of research questions. Considering the Catalan context of recent years, we can say that uncertainty is one of its main characteristics. Therefore, we propose that the emotional dimension of anxiety will affect the vote (Marcus et al., 2000; Marcus et al., 2017; Mackuen, Wolak, Keele, \& Marcus, 2010). Moreover, taking into account C's election campaign focused on alarming the negative consequences of the procés, we wonder what kind of impact this dimension will have on the vote for this party. Regarding PSC voters, we want to analyse how the three emotional dimensions affect the partisan identification on the decision of voting, since being a party with more background and history in Catalonia we intuit that the partisan identification can be a key factor. Finally, we consider how the emotional dimensions will affect the voting decision: they will act as mediating variables, or if instead, their effect will be direct.

Due to the absence of previous opinion polls in our country ${ }^{1}$ that address the analysis of emotions towards political parties or their leaders, and consequently allow us to measure their impact on the political behaviour of voters, we have made our own measurement, through the Political Study of Emotions in Catalonia to carry out the analysis. This study was conducted by the Equipo de Investigaciones Politicas of the University of Santiago de Compostela, of which the authors are members, and is a wide-ranging study aimed at examining the political situation in Catalonia following the regional elections held in 2017. The survey, whose universe was the population over 18 years old resident in Catalonia, has a sample size of 1400 interviews, proportional by sex and age quotas and distributed by province ${ }^{2}$, in a complex structure with a total of 18 thematic

${ }^{1}$ The only research centres in our country that have introduced questions regarding the analysis of the emotional component in politics have been the CIS, only in some of their studies, and the CEO. In the first case, the question is oriented to the feelings experienced towards politics in general, and in the second case, to the emotions experienced towards specific events related to the procés. In neither case are the emotions recorded, as we have already pointed out, in relation to political parties or their leaders.

${ }^{2} \mathrm{An}$ initial proportional distribution by province was not considered, because the over-representation of the population of the province of Barcelona would have significantly impoverished the results of the survey. Therefore, it was decided to slightly over-represent the provinces of Girona and Lleida, especially, and also Tarragona. Subsequently, a weighting was applied to the matrix based on the population weight of each province. 
blocks and 82 questions. The questionnaire was administered by telephone using the CATI (Computer Assisted Telephone Interviewing) system.

The principal statistical analysis technique we have opted for has been structural equation models or SEM models. This type of modeling has proved particularly effective in explaining the numerous relationships between variables in a holistic way. Specifically, as far as the analysis of the emotional component is concerned, the potential of these models lies in the possibility of analysing the existing relationships between variables freely, allowing the relationship between dimensions to be empirically and substantially significant, rather than a presumed characteristic of the structure of the emotion (Marcus et al., 2006). These are some of the fundamental arguments that, together with the findings obtained in previous studies (Jaráiz, Lagares, \& Pereira, 2020; Pereira, García, \& Castro, 2019; Lagares, Pereira, \& Rivera, 2018; Rivera \& Jaráiz, 2016; Cazorla \& Rivera, 2016), have led us to opt for this technique in order to carry out the analysis presented in these pages.

Table 2 shows the independent/exogenous variables that have been initially introduced in all the multivariate models that have been proposed, although finally only some of them are significant for the explanation of the vote in the Catalan context. Along with the variables already mentioned for measuring emotional responses to political parties, the variables of the classic models for explaining electoral behaviour stand out: 1) socio-demographic variables; 2) variables related to the analysis of the context; 3 ) ideological and identity cleavages; 4) political leadership; 5) variables specific to the current Catalan situation; and 6) partisan identification.

In relation to the analysis of the emotional component, and since it is a variable that is not usually found in political studies in Spain, as we have already advanced, we would like to make a series of clarifications regarding the way in which we have proceeded to measure it. In this study, following the proposals of Marcus et al. (2000), we opted for the use of a battery with a total of thirteen emotions ${ }^{3}$, which were studied through three questions: 1) the presence of the emotion; 2) the intensity with which the emotion/s was felt and finally; 3) the duration of the emotional expression. For more information on this subject, we recommend reviewing the contributions of Jaráiz et al. (2020). This scheme had been previously tested by the EIP in three previous studies, two at the national level and one at the municipal level, which had made it possible to refine the way in which these questions were measured, as well as to test the validity and reliability of the results.

In order for the reader to confirm this, the values obtained from the reliability analysis and the factor analysis carried out for this study are shown here (see Table 3). As can be observed, the results obtained for both analyses are in line with the values obtained in the studies carried out by Marcus et al. in 2000,

${ }^{3}$ To the initial battery proposed by Marcus et al. (2000) has been added the emotion of quiet, which had already been included in two previous studies carried out by EIP at national level and which had worked well. 
Table 2. Nature and measurement form of exogenous variables present in structural equation models.

\begin{tabular}{|c|c|c|}
\hline VARIABLE & TYPE & RESPONSE CATEGORIES \\
\hline Rating of Ciutadans opposition activity & scale & Very badly (0) - Very well (10) \\
\hline Self-positioning on the independence procés & nominal & In favour of (1) - Contrary to (2) \\
\hline Self-positioning on the application of Article 155 & nominal & In favour of (1) - Contrary to (2) \\
\hline Self-positioning regarding incarcerations & nominal & In favour of (1) - Contrary to (2) \\
\hline Rating Mariano Rajoy & scale & 0 (very badly) - 10 (very well) \\
\hline Rating Carles Puigdemont & scale & 0 (very badly) - 10 (very well) \\
\hline Rating Inés Arrimadas & scale & 0 (very badly) - 10 (very well) \\
\hline Rating Miquel Iceta & scale & 0 (very badly) - 10 (very well) \\
\hline $\begin{array}{l}\text { The intensity with which you have felt towards the } \\
\text { Catalan political parties (JxCat, ERC, Ciutadans, PSC) } \\
\text { the following emotions: pride, fear, hope, anxiety, } \\
\text { enthusiasm, anger, hatred, contempt, } \\
\text { worry, quiet, resentment, bitterness, disgust. }\end{array}$ & scale & Low intensity (0) - High intensity (5) \\
\hline Partisanship & nominal & List of Catalan political parties \\
\hline Self-positioning on the ideological scale & scale & 0 (extreme left) - 10 (extreme right) \\
\hline Self-positioning on the nationalist scale & scale & 0 (minimum nationalism) - 10 (maximum nationalism) \\
\hline Income level & continuous & $\begin{array}{l}18 \text { - } 98 \text { years } \\
\text { Up to } 300 € / \text { month (1); } \\
\text { From } 301 \text { to } 600 € / \text { month (2); } \\
\text { From } 601 \text { to } 900 € / \text { month (3); } \\
\text { From } 901 \text { to } 1200 € / \text { month (4); } \\
\text { From } 1201 \text { to } 1800 € / \text { month (5); } \\
\text { From } 1801 \text { to } 2400 € / \text { month (6); } \\
\text { From } 2401 \text { to } 3000 € / \text { month (7); } \\
\text { From } 3001 \text { to } 4500 € / \text { month (8); } \\
\text { From } 4501 \text { to } 6000 € / \text { month }(9) ; \\
\text { Over } 6000 € / \text { month (10). }\end{array}$ \\
\hline
\end{tabular}

Source: Own figures.

Table 3. Percentage of variance explained factor analysis and reliability analysis (Cronbach's Alpha values) ${ }^{4}$.

\begin{tabular}{|c|c|c|c|}
\hline & Variables & C's & PSC \\
\hline Enthusiasm Dimension & $\begin{array}{c}\text { Hope } \\
\text { Enthusiasm }\end{array}$ & 89.18 & 86.60 \\
\hline Alfa de Cronbach & $\begin{array}{l}\text { Pride } \\
\text { Quiet }\end{array}$ & 0.958 & 0.947 \\
\hline Anxiety Dimension & $\begin{array}{c}\text { Fear } \\
\text { Disgust }\end{array}$ & 78.09 & 82.66 \\
\hline Alfa de Cronbach & $\begin{array}{l}\text { Worry } \\
\text { Anger } \\
\text { Anxiety }\end{array}$ & 0.900 & 0.925 \\
\hline Aversion Dimension & $\begin{array}{c}\text { Resentment } \\
\text { Bitterness }\end{array}$ & 74.42 & 80.11 \\
\hline Alfa de Cronbach & $\begin{array}{l}\text { Contempt } \\
\text { Hatred }\end{array}$ & 0.911 & 0.935 \\
\hline
\end{tabular}

Source: Own figures.

${ }^{4}$ Following George and Mallery (1995) if the value of the statistic is greater than 0.9, the measurement instrument is excellent; in the interval $0.9-0.8$, the instrument is good; between $0.8-0.7$, the instrument is acceptable; in the interval $0.7-0.6$, the instrument is weak; between $0.6-0.5$, the instrument is poor; and finally if it is less than 0.5 , it is not acceptable. 
2006 and 2017, for the three emotional dimensions described: Enthusiasm, Anxiety and Aversion.

\section{Voter Analysis}

Without a doubt, the Catalan elections of 2015 marked a turning point with respect to the non-independent offer: C's obtained for the first time more votes than the PSC. This fact can be clearly seen in the graph below, where the evolution of the vote for both formations draws, together with the complement of the $\mathrm{PP}$, an inverse trend (Figure 1).

We may wonder how these results relate to the evolution of the procés in Catalonia and to the realignments that the parties have made around it. We mentioned above the consequences that the polarisation that has driven the Catalan issue has had on the discursive and positional simplification of the political parties regarding it. A simplification that is clearly exemplified in the proposal that they offer as a solution to the conflict and in the possible responses in the form of a political-territorial solution for the setting of Catalonia in Spain. In this sense, the PSC's programmatic change (or forgetting) about its position on the territorial conflict in the Catalan election campaign in 2015 is not trivial. Although the PSC's programmes had always made direct mention of the federal issue, in 2015 it seems that this territorial proposal is "forgotten" in its programme beyond mentioning a "social and federal Europe". This selective amnesia undoubtedly contrasts with the position of the Catalan socialists in their programmatic proposals for the 2012 Catalan elections, where they not only supported a federal Spain, but also the right to decide of the Catalan citizenship. That year, led by Pere Navarro, the PSC pointed to the unquestionable dissatisfaction and disaffection that the relationship between Catalonia and Spain was arousing among the Catalan population. Marked by the immobility of the right, they presented the federalist alternative as the only one capable of mediating

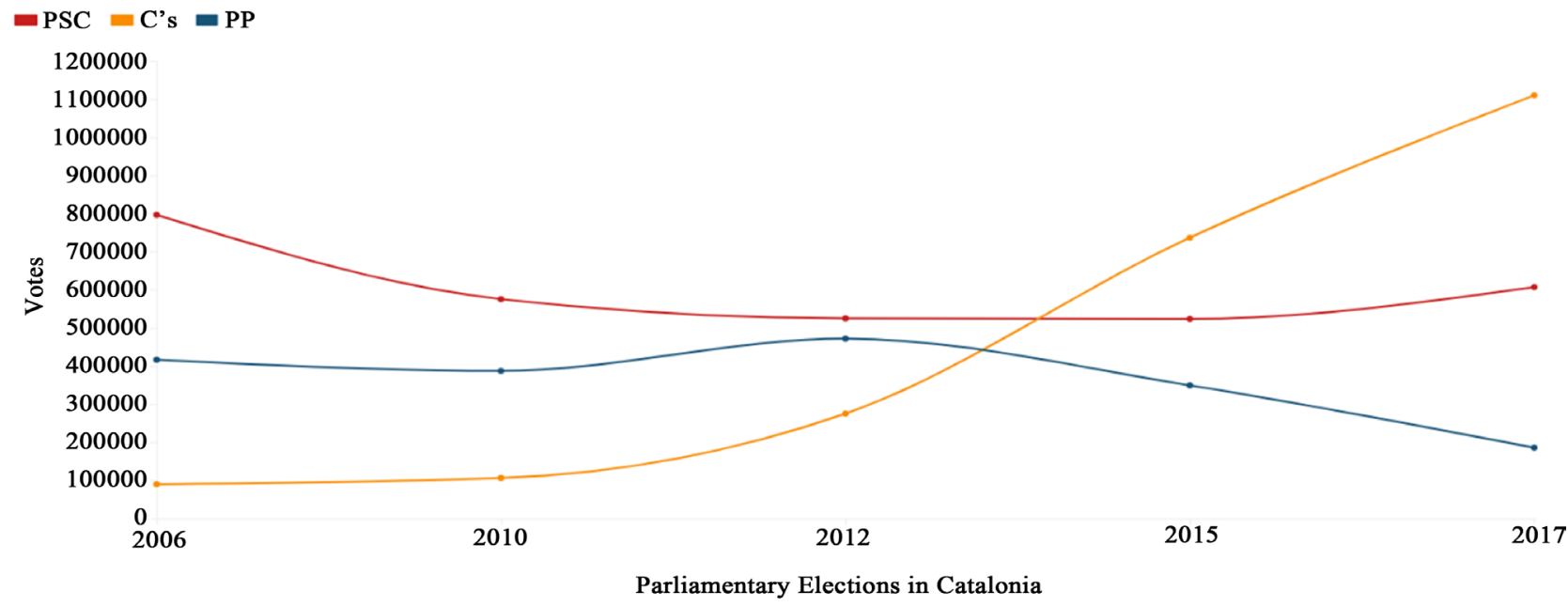

Figure 1. Parliament of catalonia. Votes by candidature. Source: Own figure based on data from the Institutd' Estadística de Catalunya (CEO). 
between the two blocks and seeking a balance between their demands and requirements. It is not only the defence of the Catalan citizenry's right to decide that may surprise us about this now almost forgotten programmatic proposal of the PSC, but also the commitment to the creation of a tax agency of the Generalitat of Catalonia.

This program, although quite "rupturist" in relation to certain more centralizing positions within the Spanish Socialist Workers Party (PSOE), was in line with what had been proposed two years earlier: in 2010 the PSC stated in its electoral program that it would work to develop the full potential of self-government of the Statute in spite of the ruling of the Tribunal Constitucional (TC) (Partit dels Socialistes de Catalunya, 2010). Obviously, we cannot ignore the fact that in 2010 the TC's ruling on the Estatut of Catalonia, approved in 2006 and endorsed by the Catalan people, was made public. The ruling declared unconstitutional 14 articles of the Estatut, relating to sovereignty, and subject to the court's interpretation 27 others. How did this decision affect the strategies of the political parties? The Catalan Socialists' electoral programme for 2012 seems to be a good example of this (Partit dels Socialistes de Catalunya, 2012), as well as their ambiguous position in 2015 which is punished by the voters (Partit dels Socialistes de Catalunya, 2015).

In 2017, we can see how programmatically the PSC takes up again the defence of federalism as the political-territorial solution that best suits the demands and needs of the situation in Catalonia (Partit dels Socialistes de Catalunya, 2017). On this occasion, the logic of dialogue, negotiation and agreements is insisted on as the only way to break the immobilism caused by the antagonistic positions of the PP and JxSí. In this programme, the PSC once again appeals directly to its commitment to “(...) autogobierno de Cataluña” (ibíd. 148), to “(...) una Cataluña con el máximo nivel de autogobierno en el seno de una España nacional" (ibíd. 141), as well as to the plurinational nature of the Spanish State.

For its part, C's maintains a clear position of opposition not only against an independent Catalonia but also against the procés and the political elite that has accompanied it, due to the social fracture they have caused. Thus, this political party insists on remaining within an Autonomous State (a cooperative federal state similar to the German model, they state in their 2015 programme) and on pointing out the negative economic consequences that independence would imply (Ciutadans de Catalunya, 2015, 2017).

Do these programmatic changes reflect a change in the socialist electorate of Catalonia with respect to the territorial question? Figure 2 and Figure 3 show how the way in which PSC and C's voters identified themselves using the Linz-Moreno scale has evolved from the year the Estatut was approved (2006) to the present year (2019). Both PSC and C's voters have been identifying themselves mostly as "I feel as Spanish as I feel Catalan". In the case of C's voters, it is striking that it is in 2010, the year in which the TC's ruling on the Estatut is published, that the percentage identifying themselves as only Spanish is highest. In this way, we can confirm the prevalence, both among the total of Catalan voters 


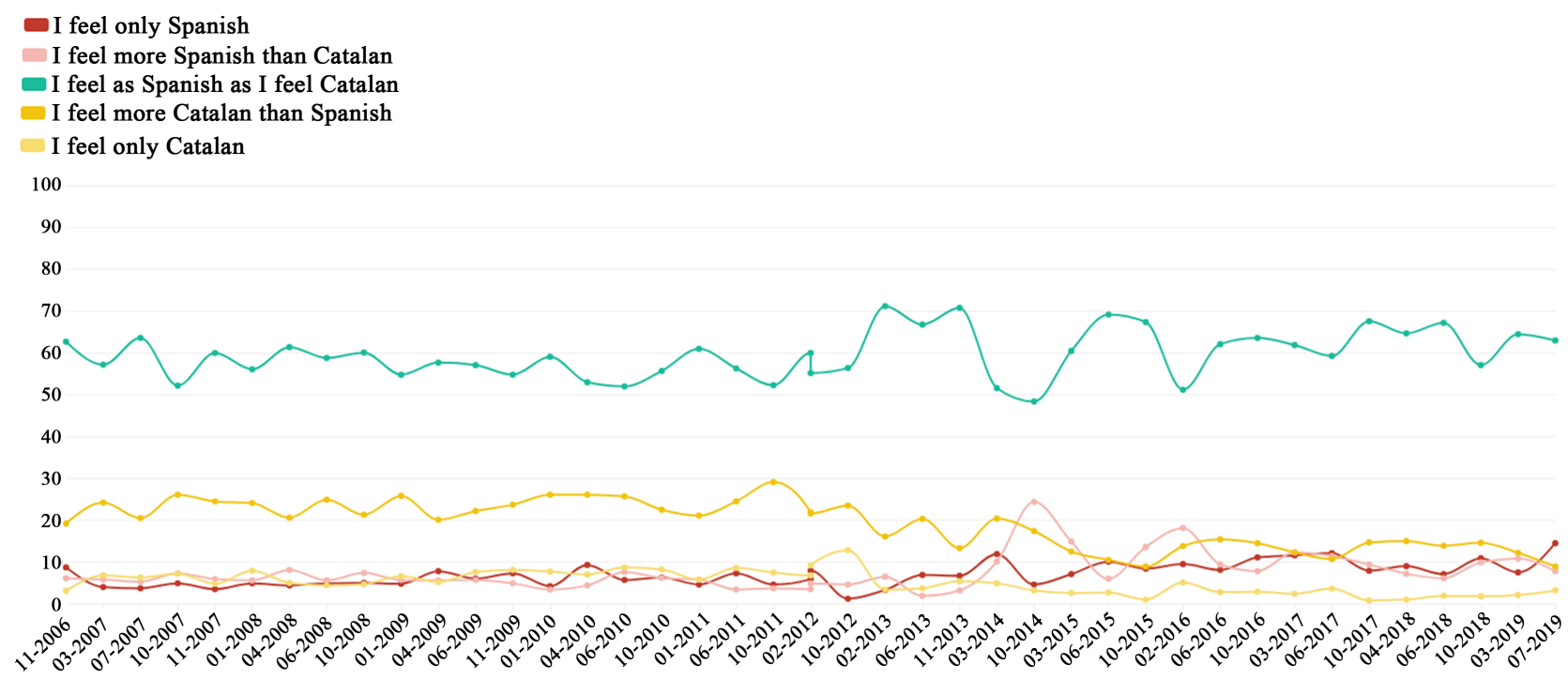

Figure 2. PSC Voter: Identification in Catalonia (2006-2019). Source: Own figure based on data from Institut d'Estadística de Catalunya (CEO).

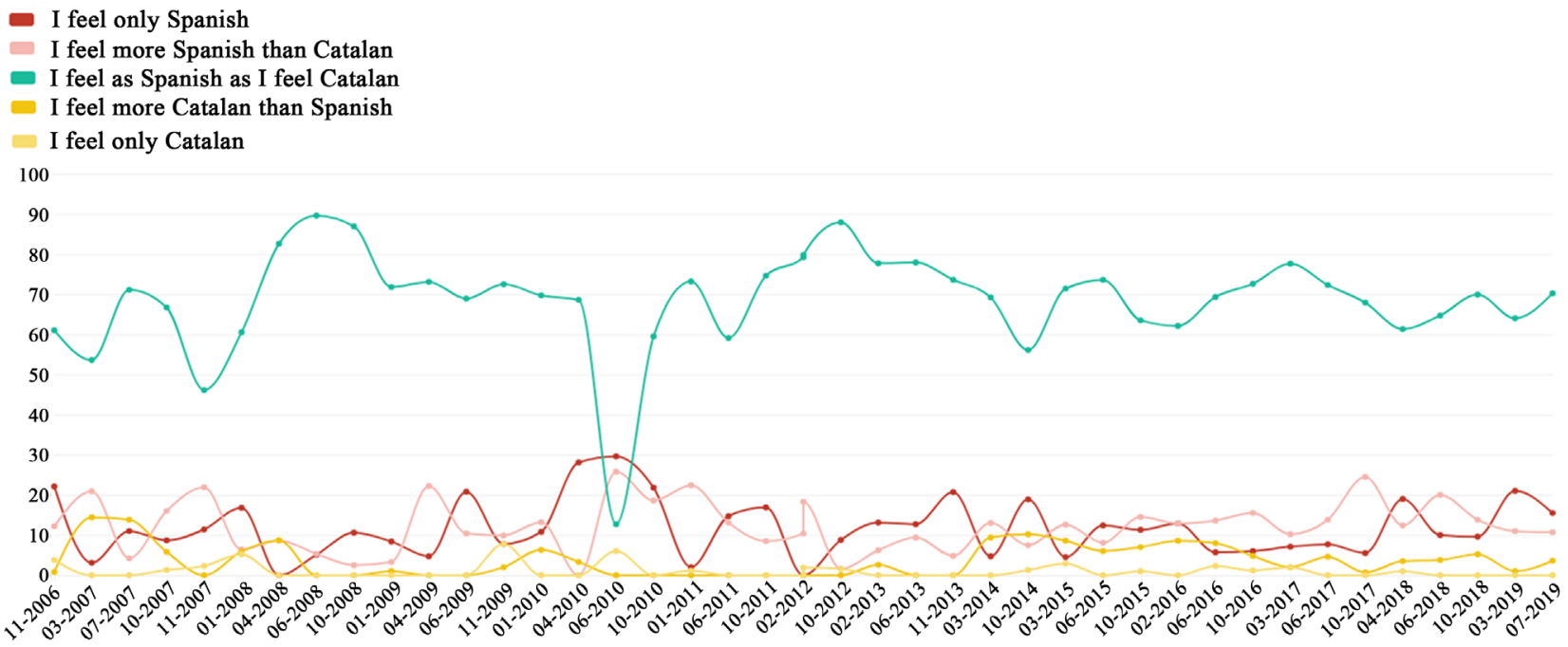

Figure 3. C's Voter: Identification in Catalonia (2006-2019). Source: Own figure based on data from Institut d'Estadística de Catalunya (CEO).

and among the voters of C's and PSC, of a sort of dual identity defined in non-exclusive terms: they identify themselves mostly as both Catalan and Spanish.

However, if we compare both figures with the data on the total number of Catalan voters (Figure 4), we see that despite the fact that this dual identity is the one that accumulates the highest percentage of response, we no longer find this difference, as in the previous figures, with respect to the second and third positions. As we can see, both the line that reflects those who have answered "I feel more Catalan than Spanish" and "I feel only Catalan" are in response percentages very close to the line corresponding to "I feel as Spanish as I feel Catalan". In fact, in this last figure, we also do not identify a pattern similar to that of the figures corresponding to the identification of PSC and C's voters. 


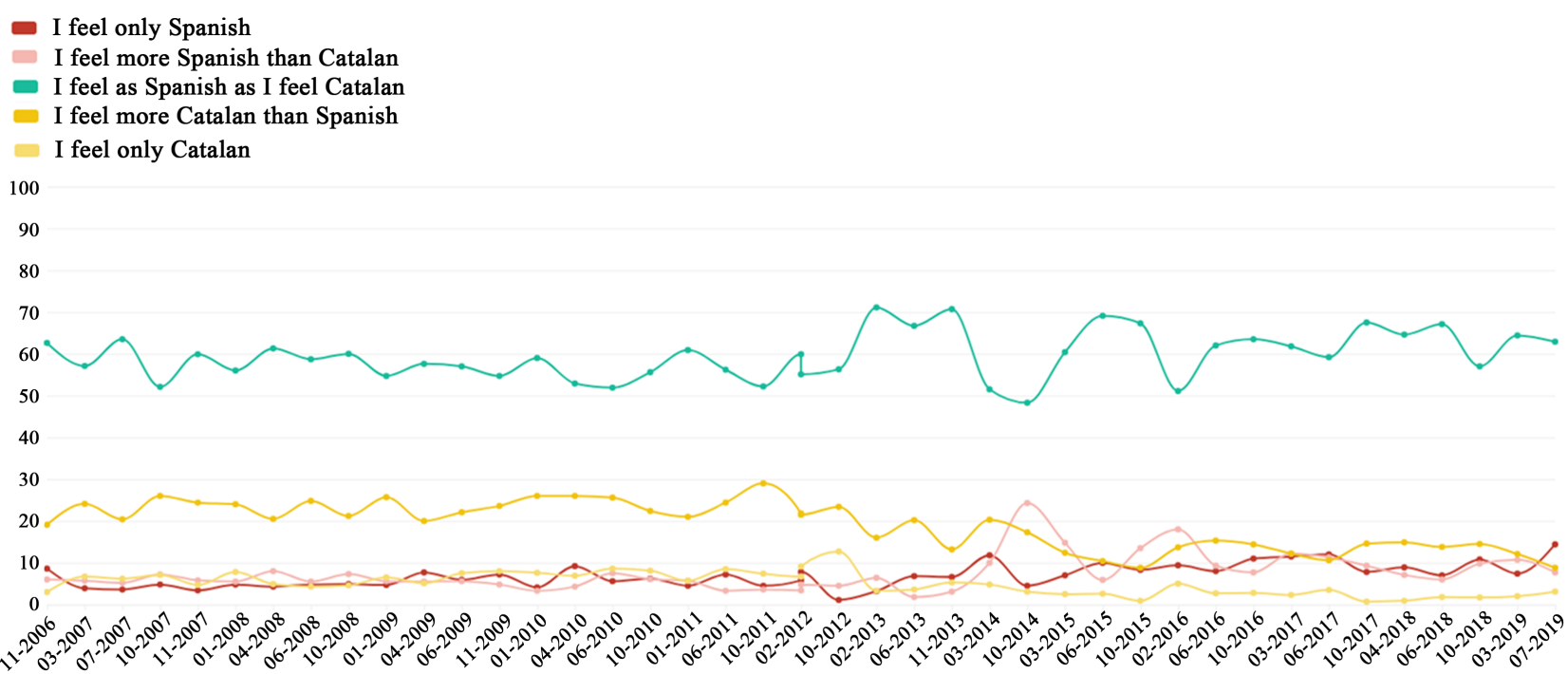

Figure 4. Identification in Catalonia (2006-2019). Source: Own figure based on data from Institut d'Estadística de Catalunya (CEO).

This leads us to wonder whether the predominance of this dual identity is translated into a political-territorial option other than Catalonia's permanence within the current Spanish state as the only alternative to independence (Máiz et al., 2018). In order to analyse the political and territorial preferences formulated by the citizens of Catalonia, we have used the survey conducted by the EIP-USC 5 , the data are shown in Table 4.

If we analyse the responses to these options in terms of the candidature they declare they voted for in the last elections to the Catalan Parliament (2017), we find that neither those who voted for C's nor those who voted for the PSC affirm that the option of independence is the one they would choose most. While C's voters opt mostly for the autonomist option $(70.3 \%)$ as opposed to the federal one (15.3\%), Socialist voters are more divided between the two options: $54.3 \%$ and $40.4 \%$ respectively. Both positions are in line with the programmatic proposals of each of these political groups. One of the questions that we ask ourselves in this paper is whether perhaps, among those who are in favour of the procés or who participated in the 10 , they do so more because of a discrepancy with the current status quo in the relationship between Catalonia and Spain, as well as because of the central government's immobility, and not so much because they believe independence is the best option for the Catalan territory (Corujo \& Viera, 2019).

If, as we have seen, the identification of PSC voters and C's voters on the Linz-Moreno scale is very similar, then why is there a difference in their political-territorial preferences? It is logical to think that probably the evaluation of ${ }^{5} \mathrm{We}$ have decided to classify the different political-territorial options that we presented to the respondents in three main blocks: 1) Federalism: a) Permanence within a Spanish federal state, b) Remaining within a Spanish federal state that recognises Catalonia as a nation; 2) Autonomous: a) Permanence within the State of Autonomies. b) Permanence within the State of Autonomies, but with a higher level of competences, c) Permanence within the State of Autonomies, but with a fiscal status comparable to that of the Basque Country and Navarre; and 3) Independence. 
Table 4. Type of political-territorial solution most suitable for Catalonia.

\begin{tabular}{|c|c|c|c|}
\hline & & C's & PSC \\
\hline \multirow{3}{*}{ Federalism } & Permanence within a Spanish federal state & $9.2 \%$ & $25.5 \%$ \\
\hline & $\begin{array}{l}\text { Remaining within a Spanish federal state that } \\
\text { recognises Catalonia as a nation. }\end{array}$ & $6.3 \%$ & $14.9 \%$ \\
\hline & Permanence within the State of Autonomies & $35.9 \%$ & $20.2 \%$ \\
\hline \multirow{2}{*}{ Autonomous } & $\begin{array}{l}\text { Permanence within the State of Autonomies. } \\
\text { but with a higher level of competences }\end{array}$ & $16.2 \%$ & $18.1 \%$ \\
\hline & $\begin{array}{l}\text { Permanence within the State of Autonomies. } \\
\text { but with a fiscal status comparable to that } \\
\text { of the Basque Country and Navarre }\end{array}$ & $16.2 \%$ & $14.9 \%$ \\
\hline Independence & & $0 \%$ & $0 \%$ \\
\hline Other options & Its permanence within a centralized state & $13.4 \%$ & $5.3 \%$ \\
\hline \multirow[t]{2}{*}{ DK/NA } & & $2.8 \%$ & $1.1 \%$ \\
\hline & Total & $100.0 \%$ & $100.0 \%$ \\
\hline
\end{tabular}

Source: Own figures.

the context is different for both groups. Analysing the prospective evaluation of the economic and political situation of Catalonia and Spain, we can observe a certain difference between the voters of these two political parties. In general terms, we could say that the voters of the political party led by Inés Arrimadas (C's) are more pessimistic about the situation in Catalonia, not only in comparison with their evaluation of the situation in Spain, but also in contrast with the evaluations of the PSC voters. It should be noted, however, that the latter also makes a more positive assessment of the future political and economic situation of Spain than that of Catalonia.

But perhaps one of the most remarkable data we found in our survey is that regarding the participation in the October 1st referendum, among PSC voters who went to the polls that day, $21.4 \%$ voted in favor while among C's voters only $5 \%$ did so. But not only this, regarding the support or not of the imprisonment of the pro-independence political leaders, $80.3 \%$ of C's voters were in favour, while $73.6 \%$ of socialist voters were against. In line with these divergent positions, we see a certain disparity in the opinion of these two voter profiles regarding the application of Article 155 of the Constitution, by which the Government can take intervention measures in an Autonomous Community. 86.5\% of C's voters supported it while the number falls to $56.5 \%$ among socialist voters (43.5\% are against). An interesting approach to why in certain contexts part of the electorate goes on to support measures of an "authoritarian" nature is that of Vasilopoulos et al. (2017) in which they state that it is the emotional reactions experienced by citizens that are the factors that most influence the acceptance of this type of measure. Thus, they point out that the voters who are located in the spectrum of the left of the ideological axis show that change of attitude when the emotional reaction they experience is what they call "anxiety". Among voters on 
the right, no such change is observed since they generally tend to be more accepting of "authoritarian" measures or policies. In this sense, a fact that should not be overlooked is that PSC voters position themselves more to the left (4.08) than C's voters $(5.47)^{6}$.

\section{Multivariate Analysis}

Once a first descriptive approach to some of the central issues included in this work has been defined, the results of the two structural equation models adjusted for the analysis of the vote for the two main non-independence parties: Ciutadans de Catalunya (C's) and the Partit dels Socialistes de Catalunya (PSC) are shown below ${ }^{7}$. In all cases, moderate degrees of explanation are achieved if we take into account the values of the Pseudo R2, and good rates of adjustment ${ }^{8}$ of the models, if we take into account the usual values of adjustment indicated by the reference literature in this regard (Kline, 2011).

Table 5 shows the diagram of the model adjusted for the explanation of vote to Ciutadans 9 . The variable that has the greatest effect on the vote for the second most voted party in the 2017 Autonomous Community elections is partisanship for said party with a total effect (0.556), also generating a positive effect on the vote for C's. The second variable that would explain the vote in positive terms would be the rating of the political opposition made by Ciutadans as the main opposition party, with a total effect on the vote of 0.379 . It is important to note the high covariation between this variable and the rating of the party leader, Inés Arrimadas (0.777).

Continuing with the variables that exert a positive effect on the vote for C's, we find the fact of being in favour of the imprisonment of pro-independence Catalan politicians, with a total effect of 0.224 . A variable whose effect on the vote was conditioned to me by the direct influence that sympathy for the political group has on it (0.225).

Next, we find the effect that the emotional component Enthusiasm has directly and indirectly through partisanship, in the vote for Ciutadans $(\mathrm{ET}=0.169)$.

Table 5. Overall levels of explanation and model fit measures.

\begin{tabular}{cccc}
\hline & Pseudo R2 & NFI & CFI \\
\hline Ciutadans voting model & 0.67 & $0, .974$ & 0.979 \\
PSC voting model & 0.61 & 0.983 & 0.987 \\
\hline
\end{tabular}

Source: Own figures.

${ }^{6}$ Averages of a scale $(0-10)$ where 0 is the maximum where the voter can place oneself on the left and 10 on the right. Data from the Equipo de Investigaciones Políticas (EIP) Political Study Emotions in Catalonia.

${ }^{7}$ The main reason for not including the analysis of EnComúPodem and PP was the number of cases that could be worked with in the sample, which significantly reduced the potential of the analysis. Beyond the questions of content already set out in previous sections.

${ }^{8}$ The reference values for the NFI and CFI global adjustment indices are as follows: 1) NFI "good": $0.95 \leq \mathrm{NFI} \leq 1.00$ and NFI "acceptable": $0.90 \leq \mathrm{NFI} \leq 0.95 ; 2) \mathrm{CFI}$ "good": $0.97 \leq \mathrm{CFI} \leq 1.00$ and CFI "acceptable": $0.95 \leq \mathrm{CFI} \leq 0.97$.

${ }^{9}$ Detailed statistics are included in the Appendix (Table A1). 
On the contrary, we observe how the emotional component Anxiety, would exercise a negative effect on the probability of voting for the formation, but not in a direct way, but indirectly through the effect on the positioning in the identity scale $(E D=0.229)$ and the positioning in favour of the imprisonments. As can be seen in the diagram, in spite of being included initially, the variable related to the emotional component Aversion, is not present in the adjusted model.

The next variable in terms of importance attending to the value of the total effects would be the self-positioning on the ideological scale (ET $=0.121)$, although this variable maintains a direct effect on the vote $(E D=0.506)$ and indirect on it through the mediation effect that generates the partisanship (EI = 0.072). We must mention, that in contrast the self-positioning on the nationalist scale, only exerts an indirect effect on the vote mediated through partisanship $(E I=-0.250)$, as opposed to the pattern observed in the case of the ideological positioning (Figure 5).

The last variable that would have a positive effect on the vote for this political party would be precisely the rating of its leader Inés Arrimadas, with a total effect of 0.115. Interesting in this sense is the effect that the leader's rating would have on the fact of being in favour of imprisonment $(E D=0.316)$ and consequently of the vote, with an indirect effect of $(\mathrm{EI}=0.071)$. However, as would be expected and as is usual in analyses of voting behaviour, the effect of leadership on the vote for this party does not only come from that expressed towards its leader, but from the antagonistic constructions of the evaluations expressed towards leaders of other formations, as is the case with the effect of the rating of M. Rajoy $(\mathrm{ET}=-0.049)$ or the rating of C. Puigdemont $(\mathrm{ET}=-0.163)$.

Finally, with regard to this model, we should mention that the only sociodemographic variable that is significant is the income level, although it is the variable that has the smallest total effect $(\mathrm{TE}=-0.035)$.

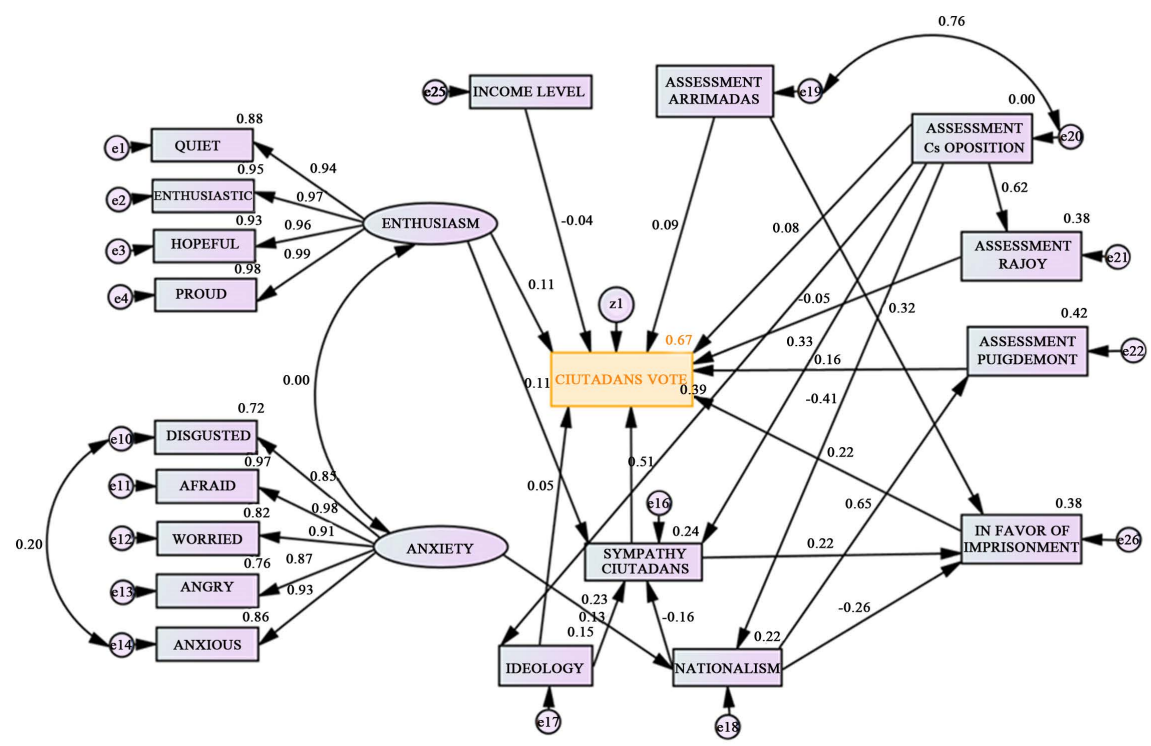

Figure 5. Ciutadans SEM voting model. Source: Own figures. 
Continuing with the explanation of the vote for the Socialist Party of Catalonia (Figure 6), we observe, with respect to some of the variables introduced, patterns similar to those described for the previous model. Again, partisanship is the variable that most conditions the vote for this party $(\mathrm{ET}=0.649)$. It is worth noting the direct effect that this variable has on the self-positioning on the independence procés $(\mathrm{ED}=0.232$ ) or on the self-positioning on the application of Article 155 (ED = -0.161); which would in turn have an indirect effect on the vote, given the direct effect that these last two variables have on the former, of 0.240 in the case of the former and -0.193 in the case of the latter. This would allow us to state that while being in favour of the application of Article 155 reduces the probability of voting for the PSC (ET $=-0.055)$, being against the independence procés ${ }^{10}$ would increase that probability $(\mathrm{ET}=0.271)$. It is convenient to point out the important relationship of correlation existing between the variables related to the procés, whose values can be observed in the diagram.

Other of the essential variables at to understand the vote to the PSC, is the emotional component Enthusiasm, that would exercise in turn a direct effect (0.200) and indirectly mediated through the partisanship for the formation (ED $=0.435$ ), what offers us a total effect of 0.499 on the vote. Regarding the other two emotional components: Aversion and Anxiety; the first, as in the previous model, is not present, while the second has a direct $(-0.100)$ and indirect $(-0.090)$ effect on the vote for this party, in a negative sense in both cases.

Similarly, to what was observed in the previous model, the positions on the ideological and identity scales have indirect effects (mediated by partisanship for the political group) on the vote for the PSC. The total effects are 0.009 and -0.255 , respectively.

With respect to the leaderships, the only leader with a significant effect on the vote for the PSC is the rating of the regional leader Miquel Iceta, with a direct effect on the vote of 0.074 . To conclude, the inverse effect that age, the only

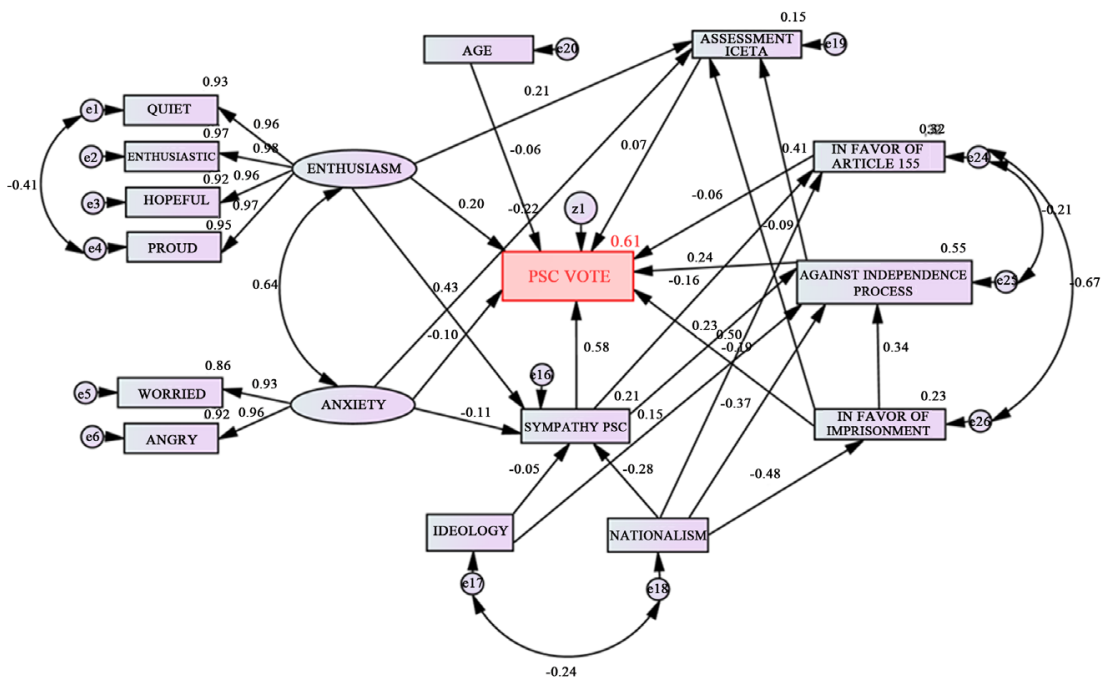

Figure 6. PSC SEM voting model. Source: Own figures.

${ }^{10}$ Detailed statistics are included in the Appendix (Table A2). 
socio-demographic variable present in the model, would be having on the vote (ET $=-0.058)$ should be pointed out; in such a way that as it increases, the probability that the individual would vote for this political party is reduced.

\section{Discussion}

In brief, it is interesting to point out some general questions regarding the analysis of the structural equation models raised, which in some cases confirm findings from previous research, and in others raise new hypotheses and lines of investigation. One of the main results to be pointed out is the importance that the classical elements of explanation of the vote have in the models proposed for these two political groups; thus confirming a long academic trajectory in this sense.

But at the same time, we note the importance of the emotional components in the explanation, which come to nourish and enrich it notably, especially in a situation of uncertainty and polarisation such as that which occurs in Catalonia. Although it is necessary to point out some important issues in this sense, since not all the emotional components initially contemplated generate effects on the vote for the formations analysed in the given context, neither in the same sense nor with the same intensity; showing the differences that exist between both and which we have tried to explain from the beginning.

With regard to the specific objectives we proposed at the beginning of this work, we would like to highlight the following results:

1) In the previous section, we analysed the specific weight of the emotional dimensions that affect the vote of C's and PSC, and we can state that although the emotional components of Enthusiasm (quiet, enthusiastic, hopeful and proud) and Anxiety (disgusted, afraid, worried, angry and anxious) show significant effects in both models, the same does not happen with the emotional component Aversion (resentful, contempt, bitter and hatred). While the latter would be largely due to the low response rate for the items that make up this latent variable, this pattern would describe a non-negative policy in general terms, which is largely consistent with the previous approaches of Marcus et al. (2000, 2006, 2017). These approaches are also of great interest with respect to the results obtained for the influence of the emotional component Anxiety, since, according to the authors, this component would be present in the individual as a response to political stimuli that are produced at new or unexpected times. The situation that Catalonia was going through before the 2017 regional elections is a clear example of an unexpected situation that would generate a state of uncertainty among voters, being able to produce in them situations of anxiety, which would explain the influence of this emotional component in both models.

2) As for the second and third research question, how does the procés affect the decision to vote, the analysis shows us some particularities in the explanation of the vote to both formations. Concerning the impact of the measures taken by the Spanish government as well as the position of those surveyed with respect to 
the procés itself, we can see how in the case of voting for the PSC, taking a position against it has a direct positive relationship, although taking a position in favour of article 155 does have a negative effect. In the case of voting for C's we can note how being in favour of the imprisonment of pro-independence leaders has a positive impact. These findings would confirm what the descriptive data previously presented in the section on voter analysis suggests.

3) Taking up again the manifest importance of the classical elements, it is important to point out the influence of the partisan identification in both equations, a matter that has already been expressed in previous studies (Jaráiz et al. 2020; Pereira et al., 2019; Lagares et al., 2018; Rivera \& Jaráiz, 2016; Cazorla \& Rivera, 2016) and that is confirmed again. But even more important are the variables that nourish it, since these modelizations allow to put in value the importance that the emotional or affective components would have on the composition of the identification; allowing to confirm the meaning that the classic studies showed in relation to it. Another fundamental finding in the line of other studies, is the importance of traditional cleavages, ideology and identity, in the direct explanation on the voting behaviour and indirect on the partisan identification, sharing this role with the emotional components, as described in previous lines. Almost to finish, to point out the scarce presence and reduced effect of the socio-demographic variables in the explanation of vote. A pattern that has been common in behavioural analyses, with the exception of age, again present here in the case of the model adjusted for the PSC. Undoubtedly, we could speak of a certain "desociologización de la política” (Jaráiz et al. 2020).

4) In sum, can we identify a single type of non-independent voter in the Catalan elections of 2017? Taking into account both the emotional dimensions and the variables related to the procés itself and the measures carried out by the Spanish government, we can affirm that despite the fact that the same variables are present in both models (Ciutadans SEM voting model and PSC voting model) they affect in a different way the vote of the two political parties. As we have seen, while in the PSC voting model the emotional dimensions (Enthusiasm and Anxiety) do so directly, in the case of voting for C's the impact of the Anxiety dimension is indirect. Likewise, the variables related to the procés and the measures carried out by the Spanish government affect each of the models in the opposite way.

\section{Conclusion}

In conclusion, it is important to note that the analysis presented in this article highlights the value that the latest events before the 2017 regional elections would have had on Catalan society as a whole in terms of polarisation, and more specifically on the voters of parties that would not support independence. These events have continued to nourish and shape the procés and are clearly mediated by the nationalist position, the identifications towards the political parties and the evaluations of the management and positioning of their leaders. 
Without a doubt, this article contributes to the empirical evidence presented in line with previous works regarding the influence and effects that the different emotional components have on the perception of politics and the decision-making process. In particular, the effect generated by the emotions linked to the Anxiety component.

Looking to the future, and especially taking into account the possibility of a new election being held in Catalonia, it is necessary to continue analysing the effect that emotions and other classic components may have on the vote of different political groups. And in this sense, it could be particularly valuable to consider the analysis, taking into account not only the emotions generated towards the political parties, but also towards their leaders, as regards the effect that the discourse and the story built by them could have, in a situation of uncertainty and polarisation such as that which Catalonia is going through, on the electorate's decision to vote.

\section{Conflicts of Interest}

The authors declare no conflicts of interest regarding the publication of this paper.

\section{References}

Cazorla, Á., \& Rivera, J. M. (2016). De la Nación Primordial a la Nación en Proceso: La Nueva Identidad Nacional Catalana. In J. M. Rivera, J. Montabes, \& N. Lagares (Eds.), Cataluña en Proceso. Las elecciones autonómicas de 2015 (pp. 261-288). Valencia: Tirant Lo Blanch.

Ciutadans de Catalunya (2015). Un projecte per la convivència. Programa electoral Eleccions Autonòmiques Catalanes 2015. https://file.lavanguardia.com/ext1/file02/2015/09/09/54436391777-url.pdf

Ciutadans de Catalunya (2017). Programa electoral por la convivencia, el sentido común y la unión elecciones al parlament de catalunya/2017. https://www.ciudadanos-cs.org/propuestas-para-catalunya

Corujo, A., \& Viera, A. (2019). El elector federalista catalán como solución (parcial) al reto independentista. Revista de Investigaciones Políticas y Sociológicas, 18, 67-94. https://doi.org/10.15304/rips.18.1.5818

George, D., \& Mallery, P. (1995). SPSS/Pc: A Simple Guide and Reference Step by Step. Belmont, CA: Wadswortg Publishing Company.

Jaráiz, E., Lagares, N., \& Pereira, M. (2020). Emociones y decisión de voto. Los componentes de voto en las elecciones generales de 2016 en España. Revista Española de Investigaciones Sociológicas, 170, 95-116. (en prensa) http://dx.doi.org/10.5477/cis/reis.170.95

Kline, R. B. (2011). Principles and Practice of Structural Equation Modeling. New York: The Guilford Press.

Lagares, N., Pereira, M., \& Rivera, J. M. (2018). Diferencias y homogeneidades en el voto a Podemos y sus confluencias. In F. Llera, J. Montabes, \& M. Baras (Eds.), Las elecciones generales de 2015 y 2016 (227-248). Madrid: Centro de Investigaciones Sociológicas.

MacKuen, M., Wolak, J., Keele, L., \& Marcus, G. E. (2010). Civic Engagements: Resolute Partisanship or Reflective Deliberation. American Journal of Political Science, 54, 
440-458. https://doi.org/10.1111/j.1540-5907.2010.00440.x

Máiz, R., \& Lagares, N. (2017). El espacio político del federalismo en Cataluña. In J. M. Rivera, J. Montabes, \& N. Lagares (Eds.), Cataluña en Proceso. Las elecciones autonómicas de 2015 (pp. 289-321). Valencia: Tirant lo Blanch.

Máiz, R. (2010). La hazaña de la razón: La exclusión fundacional de las emociones en la teoría política moderna. Revista de Estudios Políticos, 149, 11-45.

Máiz, R., Lagares, N., \& Pereira, M. (2018). Catalonia: Federalism or Secession? Open Journal of Political Science, 8, 495-524. https://doi.org/10.4236/ojps.2018.84031

Marcus, G. E. (2000). Emotions in Politics. In N. W. Polsby (Ed.), Annual Review of Political Science (p. 3). Palo Alto, CA: Annual Reviews. https://doi.org/10.1146/annurev.polisci.3.1.221

Marcus, G. E., MacKuen, M., Wolak, J., \& Keel, L. (2006). The Measure and Mismeasure of Emotion. In D. Redlawsk (Ed.), Feeling Politics: Emotion in Political Information Processing (pp. 31-45). New York: Palgrave Macmillan. https://doi.org/10.1057/9781403983114_3

Marcus, G. E., Neuman, R. W., \& MacKuen, M. B. (2017). Measuring Emotional Response: Comparing Alternative Approaches to Measurement. Journal of Political Science Research and Methods, 5, 733-754. https://doi.org/10.1017/psrm.2015.65

Marcus, G. E., Neuman, W. R., \& MacKuen, M. B. (2000). Affective Intelligence and Political Judgment. Chicago, IL: University of Chicago Press.

Partit dels Socialistes de Catalunya (2010). Programa electoral per a les eleccions al Parlament de Catalunya 2010. Una Catalunya mésforta, una societatmés justa. http://www.socialistes.cat/files/2010_programa_eleccions_al_parlament_de_catalunya_ 2010_cat.pdf

Partit dels Socialistes de Catalunya (2012). Eleccions al Parlament de Catalunya 2012. Programa Electoral. L'alternativa sensata.

http://www.rtve.es/contenidos/documentos/programa_psc_elecciones_catalanas_2012. pdf

Partit dels Socialistes de Catalunya (2015). Nuestro compromiso. Soluciones justas y acordadas. Programa electoral del PSC para las elecciones catalanas del 27 de septiembre de 2015. http://www.socialistes.cat/pagina/solucions-justes-i-acordades

Partit dels Socialistes de Catalunya (2017). Elecciones al Parlament de Catalunya. 21 de diciembre de 2017. Soluciones ahora, Iceta! http://www.socialistes.cat/pagina/eleccions-2017-programa-electoral

Pereira, M., García, A., \& Castro, P. (2019). La protesta y el voto? Cuánto hay de protesta en el voto a los nuevos partidos? In N. Lagares, C. Ortega, \& P. Oñate (Eds.), Las elecciones autonómicas de 2015 y 2016 (319-345). Madrid: Centro de Investigaciones Sociológicas.

Rivera, J. M., \& Jaráiz, E. (2016). Modelos de explicación y componentes del voto en las elecciones autonómicas catalanas de 2015. Revista Española de Ciencia Política, 42, 13-43. https://doi.org/10.21308/recp.42.01

Vasilopoulos, P., \& Marcus, G. E. (2017). Deux voies vers la droite: Enjeux, émotions et vote FN. In O. Fillieule, F. Haegel, C. Hamidi, \& V. Tiberj (Eds.), Sociologieplurielle des comportements politiques (289-320). Paris: Sciences Po Les Presses.

Vasilopoulos, P., Marcus, G. E., \& Foucault, M. (2017). Emotional Responses to the Charlie Hebdo Attacks: Addressing the Authoritarianism Puzzle. Political Psychology, 20, 1-18. https://doi.org/10.1111/pops.12439 


\section{Annexes}

Table A1. Total, direct and indirect effects of the vote on Ciutadans.

\begin{tabular}{|c|c|c|c|c|c|c|c|c|c|c|c|}
\hline \multicolumn{12}{|c|}{ Standarized Total Effects } \\
\hline & Enthusiasm & Anxiety & $\begin{array}{l}\text { Assessm. } \\
\text { Oposit. Cs }\end{array}$ & Ideology & Nationalism & $\begin{array}{l}\text { Sympathy } \\
\text { Ciutadans }\end{array}$ & $\begin{array}{l}\text { Assessm. } \\
\text { Arrimadas }\end{array}$ & $\begin{array}{c}\text { Income } \\
\text { level }\end{array}$ & $\begin{array}{l}\text { In favor of } \\
\text { Imprison. }\end{array}$ & $\begin{array}{c}\text { Assessm. } \\
\text { Rajoy }\end{array}$ & $\begin{array}{l}\text { Assessem. } \\
\text { Puigdemont }\end{array}$ \\
\hline Ideology & 0.000 & 0.000 & 0.385 & 0.000 & 0.000 & 0.000 & 0.000 & 0.000 & 0.000 & 0.000 & 0.000 \\
\hline Nationalism & 0.000 & 0.229 & -0.408 & 0.000 & 0.000 & 0.000 & 0.000 & 0.000 & 0.000 & 0.000 & 0.000 \\
\hline $\begin{array}{l}\text { Sympathy } \\
\text { Ciutadans }\end{array}$ & 0.108 & -0.036 & 0.439 & 0.129 & -0.156 & 0.000 & 0.000 & 0.000 & 0.000 & 0.000 & 0.000 \\
\hline $\begin{array}{c}\text { In favor of } \\
\text { Imprisonments }\end{array}$ & 0.024 & -0.067 & 0.204 & 0.029 & -0.294 & 0.225 & 0.316 & 0.000 & 0.000 & 0.000 & 0.000 \\
\hline $\begin{array}{l}\text { Assessment } \\
\text { Rajoy }\end{array}$ & 0.000 & 0.000 & 0.619 & 0.000 & 0.000 & 0.000 & 0.000 & 0.000 & 0.000 & 0.000 & 0.000 \\
\hline $\begin{array}{l}\text { Assessement } \\
\text { Puigdemont }\end{array}$ & 0.000 & 0.148 & -0.263 & 0.000 & 0.646 & 0.000 & 0.000 & 0.000 & 0.000 & 0.000 & 0.000 \\
\hline Disgusted & 0.000 & 0.848 & 0.000 & 0.000 & 0.000 & 0.000 & 0.164 & 0.000 & 0.000 & 0.000 & 0.000 \\
\hline Afraid & 0.000 & 0.985 & 0.000 & 0.000 & 0.000 & 0.000 & 0.000 & 0.000 & 0.000 & 0.000 & 0.000 \\
\hline Worried & 0.000 & 0.908 & 0.000 & 0.000 & 0.000 & 0.000 & 0.000 & 0.000 & 0.000 & 0.000 & 0.000 \\
\hline Angry & 0.000 & 0.873 & 0.000 & 0.000 & 0.000 & 0.000 & 0.000 & 0.000 & 0.000 & 0.000 & 0.000 \\
\hline Anxious & 0.000 & 0.927 & 0.000 & 0.000 & 0.000 & 0.000 & 0.000 & 0.000 & 0.000 & 0.000 & 0.000 \\
\hline Quite & 0.939 & 0.000 & 0.000 & 0.000 & 0.000 & 0.000 & 0.000 & 0.000 & 0.000 & 0.000 & 0.000 \\
\hline Enthusiastic & 0.974 & 0.000 & 0.000 & 0.000 & 0.000 & 0.000 & 0.000 & 0.000 & 0.000 & 0.000 & 0.000 \\
\hline Hopeful & 0.964 & 0.000 & 0.000 & 0.000 & 0.000 & 0.000 & 0.000 & 0.000 & 0.000 & 0.000 & 0.000 \\
\hline Proud & 0.988 & 0.000 & 0.000 & 0.000 & 0.000 & 0.000 & 0.000 & 0.000 & 0.000 & 0.000 & 0.000 \\
\hline $\begin{array}{c}\text { CIUTADANS } \\
\text { VOTE }\end{array}$ & 0.169 & -00.057 & 0.379 & 0.121 & -0.250 & 0.556 & 0.115 & -0.035 & 0.224 & -0.049 & -163 \\
\hline
\end{tabular}

\section{Standarized Direct Effects}

\begin{tabular}{|c|c|c|c|c|c|c|c|c|c|c|c|}
\hline & Enthusiasm & Anxiety & $\begin{array}{l}\text { Assessm. } \\
\text { Oposit. Cs }\end{array}$ & Ideology & Nationalism & $\begin{array}{l}\text { Sympathy } \\
\text { Ciutadans }\end{array}$ & $\begin{array}{l}\text { Assessm. } \\
\text { Arrimadas }\end{array}$ & $\begin{array}{c}\text { Income } \\
\text { level }\end{array}$ & $\begin{array}{l}\text { In favor of } \\
\text { Imprison. }\end{array}$ & $\begin{array}{c}\text { Assessm. } \\
\text { Rajoy }\end{array}$ & $\begin{array}{c}\text { Assessem. } \\
\text { Puigdemont }\end{array}$ \\
\hline Ideology & 0.000 & 0.000 & 0.385 & 0.000 & 0.000 & 0.000 & 0.000 & 0.000 & 0.000 & 0.000 & 0.000 \\
\hline Nationalism & 0.000 & 0.229 & -0.408 & 0.000 & 0.000 & 0.000 & 0.000 & 0.000 & 0.000 & 0.000 & 0.000 \\
\hline $\begin{array}{l}\text { Sympathy } \\
\text { Ciutadans }\end{array}$ & 0.108 & 0.000 & 0.326 & 0.129 & -0.156 & 0.000 & 0.000 & 0.000 & 0.000 & 0.000 & 0.000 \\
\hline $\begin{array}{c}\text { In favor of } \\
\text { Imprisonments }\end{array}$ & 0.000 & 0.000 & 0.000 & 0.000 & -0.258 & 0.225 & 0.316 & 0.000 & 0.000 & 0.000 & 0.000 \\
\hline $\begin{array}{l}\text { Assessment } \\
\text { Rajoy }\end{array}$ & 0.000 & 0.000 & 0.619 & 0.000 & 0.000 & 0.000 & 0.000 & 0.000 & 0.000 & 0.000 & 0.000 \\
\hline $\begin{array}{l}\text { Assessement } \\
\text { Puigdemont }\end{array}$ & 0.000 & 0.000 & 0.000 & 0.000 & 0.646 & 0.000 & 0.000 & 0.000 & 0.000 & 0.000 & 0.000 \\
\hline
\end{tabular}




\section{Continued}

\begin{tabular}{|c|c|c|c|c|c|c|c|c|c|c|c|}
\hline Disgusted & 0.000 & 0.848 & 0.000 & 0.000 & 0.000 & 0.000 & 0.000 & 0.000 & 0.000 & 0.000 & 0.000 \\
\hline Afraid & 0.000 & 0.985 & 0.000 & 0.000 & 0.000 & 0.000 & 0.000 & 0.000 & 0.000 & 0.000 & 0.000 \\
\hline Worried & 0.000 & 0.908 & 0.000 & 0.000 & 0.000 & 0.000 & 0.000 & 0.000 & 0.000 & 0.000 & 0.000 \\
\hline Angry & 0.000 & 0.872 & 0.000 & 0.000 & 0.000 & 0.000 & 0.000 & 0.000 & 0.000 & 0.000 & 0.000 \\
\hline Quite & 0.939 & 0.000 & 0.000 & 0.000 & 0.000 & 0.000 & 0.000 & 0.000 & 0.000 & 0.000 & 0.000 \\
\hline Enthusiastic & 0.974 & 0.000 & 0.000 & 0.000 & 0.000 & 0.000 & 0.000 & 0.000 & 0.000 & 0.000 & 0.000 \\
\hline Hopeful & 0.964 & 0.000 & 0.000 & 0.000 & 0.000 & 0.000 & 0.000 & 0.000 & 0.000 & 0.000 & 0.000 \\
\hline Proud & 0.988 & 0.000 & 0.000 & 0.000 & 0.000 & 0.000 & 0.000 & 0.000 & 0.000 & 0.000 & 0.000 \\
\hline $\begin{array}{c}\text { CIUTADANS } \\
\text { VOTE }\end{array}$ & 0.109 & 0.000 & 0.080 & 0.049 & 0.000 & 0.506 & 0.093 & -0.035 & 0.224 & -0.049 & -163 \\
\hline
\end{tabular}

\section{Standarized Indirect Effects}

\begin{tabular}{|c|c|c|c|c|c|c|c|c|c|c|c|}
\hline & Enthusiasm & Anxiety & $\begin{array}{l}\text { Assessm. } \\
\text { Oposit. Cs }\end{array}$ & Ideology & Nationalism & $\begin{array}{l}\text { Sympathy } \\
\text { Ciutadans }\end{array}$ & $\begin{array}{l}\text { Assessm. } \\
\text { Arrimadas }\end{array}$ & $\begin{array}{c}\text { Income } \\
\text { level }\end{array}$ & $\begin{array}{l}\text { In favor of } \\
\text { Imprison. }\end{array}$ & $\begin{array}{c}\text { Assessm. } \\
\text { Rajoy }\end{array}$ & $\begin{array}{l}\text { Assessem. } \\
\text { Puigdemont }\end{array}$ \\
\hline Ideology & 0.000 & 0.000 & 0.000 & 0.000 & 0.000 & 0.000 & 0.000 & 0.000 & 0.000 & 0.000 & 0.000 \\
\hline Nationalism & 0.000 & 0.000 & 0.113 & 0.000 & 0.000 & 0.000 & 0.000 & 0.000 & 0.000 & 0.000 & 0.000 \\
\hline $\begin{array}{l}\text { Sympathy } \\
\text { Ciutadans }\end{array}$ & 0.000 & -0.036 & 0.204 & 0.000 & 0.000 & 0.000 & 0.000 & 0.000 & 0.000 & 0.000 & 0.000 \\
\hline $\begin{array}{c}\text { In favor of } \\
\text { Imprisonments }\end{array}$ & 0.024 & -0.067 & 0.000 & 0.029 & -0.035 & 0.000 & 0.000 & 0.000 & 0.000 & 0.000 & 0.000 \\
\hline $\begin{array}{c}\text { Assessment } \\
\text { Rajoy }\end{array}$ & 0.000 & 0.000 & -0.263 & 0.000 & 0.000 & 0.000 & 0.000 & 0.000 & 0.000 & 0.000 & 0.000 \\
\hline $\begin{array}{l}\text { Assessement } \\
\text { Puigdemont }\end{array}$ & 0.000 & 0.148 & 0.000 & 0.000 & 0.000 & 0.000 & 0.000 & 0.000 & 0.000 & 0.000 & 0.000 \\
\hline Disgusted & 0.000 & 0.000 & 0.000 & 0.000 & 0.000 & 0.000 & 0.000 & 0.000 & 0.000 & 0.000 & 0.000 \\
\hline Afraid & 0.000 & 0.000 & 0.000 & 0.000 & 0.000 & 0.000 & 0.000 & 0.000 & 0.000 & 0.000 & 0.000 \\
\hline Worried & 0.000 & 0.000 & 0.000 & 0.000 & 0.000 & 0.000 & 0.000 & 0.000 & 0.000 & 0.000 & 0.000 \\
\hline Angry & 0.000 & 0.000 & 0.000 & 0.000 & 0.000 & 0.000 & 0.000 & 0.000 & 0.000 & 0.000 & 0.000 \\
\hline Anxious & 0.000 & 0.000 & 0.000 & 0.000 & 0.000 & 0.000 & 0.000 & 0.000 & 0.000 & 0.000 & 0.000 \\
\hline Quite & 0.000 & 0.000 & 0.000 & 0.000 & 0.000 & 0.000 & 0.000 & 0.000 & 0.000 & 0.000 & 0.000 \\
\hline Enthusiastic & 0.000 & 0.000 & 0.000 & 0.000 & 0.000 & 0.000 & 0.000 & 0.000 & 0.000 & 0.000 & 0.000 \\
\hline Hopeful & 0.000 & 0.000 & 0.000 & 0.000 & 0.000 & 0.000 & 0.000 & 0.000 & 0.000 & 0.000 & 0.000 \\
\hline Proud & 0.000 & 0.000 & 0.000 & 0.000 & 0.000 & 0.000 & 0.000 & 0.000 & 0.000 & 0.000 & 0.000 \\
\hline $\begin{array}{c}\text { CIUTADANS } \\
\text { VOTE }\end{array}$ & 0.060 & -0.057 & 0.299 & 0.072 & -0.250 & 0.050 & 0.071 & 0.000 & 0.000 & 0.000 & 0.000 \\
\hline
\end{tabular}

Source: Own figures. 
Table A2. Total, direct and indirect effects of the vote on PSC.

\begin{tabular}{|c|c|c|c|c|c|c|c|c|c|c|}
\hline \multicolumn{11}{|c|}{ Standarized Total Effects } \\
\hline & Enthusiasm & Anxiety & Ideology & Nationalism & $\begin{array}{l}\text { In favor of } \\
\text { Imprison. }\end{array}$ & $\begin{array}{l}\text { Sympathy } \\
\text { PSC }\end{array}$ & $\begin{array}{c}\text { Against } \\
\text { Independence } \\
\text { procés }\end{array}$ & Age & $\begin{array}{c}\text { Assessm. } \\
\text { Iceta }\end{array}$ & $\begin{array}{l}\text { In favor of } \\
\text { article } 155\end{array}$ \\
\hline $\begin{array}{c}\text { In favor of } \\
\text { Imprisonments }\end{array}$ & 0.000 & 0.000 & 0.000 & -0.478 & 0.000 & 0.000 & 0.000 & 0.000 & 0.000 & 0.000 \\
\hline Sympathy PSC & 0.435 & -0.115 & -0.050 & -0.276 & 0.000 & 0.000 & 0.000 & 0.000 & 0.000 & 0.000 \\
\hline $\begin{array}{c}\text { Against } \\
\text { independence procés }\end{array}$ & 0.101 & -0.027 & 0.140 & -0.596 & 0.336 & 0.232 & 0.000 & 0.000 & 0.000 & 0.000 \\
\hline Assessment Iceta & 0.256 & -0.227 & 0.057 & -0.198 & 0.044 & 0.095 & 0.407 & 0.000 & 0.000 & 0.000 \\
\hline In favor of article 155 & -0.070 & 0.018 & 0.008 & 0.543 & 0.000 & -0.161 & 0.000 & 0.000 & 0.000 & 0.000 \\
\hline Worried & 0.000 & 0.929 & 0.000 & 0.000 & 0.000 & 0.000 & 0.000 & 0.000 & 0.000 & 0.000 \\
\hline Angry & 0.000 & 0.960 & 0.000 & 0.000 & 0.000 & 0.000 & 0.000 & 0.000 & 0.000 & 0.000 \\
\hline Quite & 0.965 & 0.000 & 0.000 & 0.000 & 0.000 & 0.000 & 0.000 & 0.000 & 0.000 & 0.000 \\
\hline Enthusiastic & 0.984 & 0.000 & 0.000 & 0.000 & 0.000 & 0.000 & 0.000 & 0.000 & 0.000 & 0.000 \\
\hline Hopeful & 0.957 & 0.000 & 0.000 & 0.000 & 0.000 & 0.000 & 0.000 & 0.000 & 0.000 & 0.000 \\
\hline Proud & 0.972 & 0.000 & 0.000 & 0.000 & 0.000 & 0.000 & 0.000 & 0.000 & 0.000 & 0.000 \\
\hline PSC VOTE & 0.499 & -0.191 & 0.009 & -0.255 & -0.109 & 0.649 & 0.271 & -0.058 & 0.074 & -0.055 \\
\hline \multicolumn{11}{|c|}{ Standarized Direct Effects } \\
\hline & Enthusiasm & Anxiety & Ideology & Nationalism & $\begin{array}{l}\text { In favor of } \\
\text { Imprison. }\end{array}$ & $\begin{array}{c}\text { Sympathy } \\
\text { PSC }\end{array}$ & $\begin{array}{c}\text { Against } \\
\text { Independence } \\
\text { procés }\end{array}$ & Age & $\begin{array}{c}\text { Assessm. } \\
\text { Iceta }\end{array}$ & $\begin{array}{l}\text { In favor of } \\
\text { article } 155\end{array}$ \\
\hline $\begin{array}{c}\text { In favor of } \\
\text { Imprisonments }\end{array}$ & 0.000 & 0.000 & 0.000 & -0.478 & 0.000 & 0.000 & 0.000 & 0.000 & 0.000 & 0.000 \\
\hline Sympathy PSC & 0.435 & -0.115 & 0.050 & -0.276 & 0.000 & 0.000 & 0.000 & 0.000 & 0.000 & 0.000 \\
\hline $\begin{array}{c}\text { Against } \\
\text { independence procés }\end{array}$ & 0.000 & 0.000 & 0.151 & -0.371 & 0.336 & 0.232 & 0.000 & 0.000 & 0.000 & 0.000 \\
\hline Assessment Iceta & 0.215 & -0.217 & 0.000 & 0.000 & -0.093 & 0.000 & 0.407 & 0.000 & 0.000 & 0.000 \\
\hline In favor of article 155 & 0.000 & 0.000 & 0.000 & 0.499 & 0.000 & -0.161 & 0.000 & 0.000 & 0.000 & 0.000 \\
\hline Worried & 0.000 & 0.929 & 0.000 & 0.000 & 0.000 & 0.000 & 0.000 & 0.000 & 0.000 & 0.000 \\
\hline Angry & 0.000 & 0.960 & 0.000 & 0.000 & 0.000 & 0.000 & 0.000 & 0.000 & 0.000 & 0.000 \\
\hline Quite & 0.965 & 0.000 & 0.000 & 0.000 & 0.000 & 0.000 & 0.000 & 0.000 & 0.000 & 0.000 \\
\hline Enthusiastic & 0.984 & 0.000 & 0.000 & 0.000 & 0.000 & 0.000 & 0.000 & 0.000 & 0.000 & 0.000 \\
\hline Hopeful & 0.957 & 0.000 & 0.000 & 0.000 & 0.000 & 0.000 & 0.000 & 0.000 & 0.000 & 0.000 \\
\hline Proud & 0.972 & 0.000 & 0.000 & 0.000 & 0.000 & 0.000 & 0.000 & 0.000 & 0.000 & 0.000 \\
\hline PSC VOTE & 0.200 & -0.100 & 0.000 & 0.000 & -0.193 & 0.577 & 0.240 & -0.058 & 0.074 & -0.055 \\
\hline
\end{tabular}




\begin{tabular}{|c|c|c|c|c|c|c|c|c|c|c|}
\hline \multicolumn{11}{|c|}{ Standarized Indirect Effects } \\
\hline & Enthusiasm & Anxiety & Ideology & Nationalism & $\begin{array}{l}\text { In favor of } \\
\text { Imprison. }\end{array}$ & $\begin{array}{l}\text { Sympathy } \\
\text { PSC }\end{array}$ & $\begin{array}{c}\text { Against } \\
\text { Independence } \\
\text { procés }\end{array}$ & Age & $\begin{array}{l}\text { Assessm. } \\
\text { Iceta }\end{array}$ & $\begin{array}{l}\text { In favor of } \\
\text { article } 155\end{array}$ \\
\hline $\begin{array}{c}\text { In favor of } \\
\text { Imprisonments }\end{array}$ & 0.000 & 0.000 & 0.000 & 0.000 & 0.000 & 0.000 & 0.000 & 0.000 & 0.000 & 0.000 \\
\hline Sympathy PSC & 0.000 & 0.000 & 0.000 & 0.000 & 0.000 & 0.000 & 0.000 & 0.000 & 0.000 & 0.000 \\
\hline $\begin{array}{c}\text { Against independence } \\
\text { procés }\end{array}$ & 0.101 & -0.027 & -0.012 & 0.225 & 0.000 & 0.000 & 0.000 & 0.000 & 0.000 & 0.000 \\
\hline Assessment Iceta & 0.041 & -0.011 & 0.057 & -0.198 & 0.137 & 0.095 & 0.000 & 0.000 & 0.000 & 0.000 \\
\hline In favor of article 155 & -0.070 & 0.018 & 0.008 & 0.044 & 0.000 & 0.000 & 0.000 & 0.000 & 0.000 & 0.000 \\
\hline Worried & 0.000 & 0.000 & 0.000 & 0.000 & 0.000 & 0.000 & 0.000 & 0.000 & 0.000 & 0.000 \\
\hline Angry & 0.000 & 0.000 & 0.000 & 0.000 & 0.000 & 0.000 & 0.000 & 0.000 & 0.000 & 0.000 \\
\hline Quite & 0.000 & 0.000 & 0.000 & 0.000 & 0.000 & 0.000 & 0.000 & 0.000 & 0.000 & 0.000 \\
\hline Enthusiastic & 0.000 & 0.000 & 0.000 & 0.000 & 0.000 & 0.000 & 0.000 & 0.000 & 0.000 & 0.000 \\
\hline Hopeful & 0.000 & 0.000 & 0.000 & 0.000 & 0.000 & 0.000 & 0.000 & 0.000 & 0.000 & 0.000 \\
\hline Proud & 0.000 & 0.000 & 0.000 & 0.000 & 0.000 & 0.000 & 0.000 & 0.000 & 0.000 & 0.000 \\
\hline PSC VOTE & 0.298 & -0.090 & 0.009 & -0.255 & 0.084 & 0.072 & 0.030 & 0.000 & 0.000 & 0.000 \\
\hline
\end{tabular}

Source: Own figures. 